\title{
19. ORGANIC PETROGRAPHY OF LOWER CRETACEOUS SHALES AT DSDP LEG 47B SITE 398, VIGO SEAMOUNT, EASTERN NORTH ATLANTIC
}

\author{
Chris Cornford, Kernforschungsanlage Jülich GmbH, Erdöl und Organische Geochemie, \\ 5170 Jülich, Western Germany
}

\begin{abstract}
The type and maturity of the organic matter of the Lower Cretaceous shales of DSDP Site 398 are investigated by microscopy. The sediments are shown to contain a predominance of particles of higher plant origin. Both bimodal vitrinite reflectance histograms and anomalous fluorescence indicate the presence of recycled organic matter. The relative content of recycled particles is quantified, and the origin discussed. Recycled organic particles reach a peak in the Albian and Aptian of the Lower Creteceous. A low maturity gradient is indicated with vitrinite reflectance values in the 0.5 to 0.6 per cent range at 1700 meters. The sediments are considered as fair liquid hydrocarbon source rocks, but are immature.
\end{abstract}

\section{INTRODUCTION}

On Leg 47B of the Deep Sea Drilling Project, we drilled Site 398 on the edge of the Vigo Seamount, halfway between the mainland of Portugal and Galicia Bank (Figure 1). A major objective at this site was to obtain samples of Mesozoic sediment deposited during the early rifting stage of the North Atlantic. The hole penetrated Tertiary and Cretaceous sediments, terminating in Hauterivian mudstones at 1740 meters (Figure 2).

\section{SAMPLES}

As shown in Table 1, 23 samples were collected onboard ship and include some residues of the shipboard "carbonate bomb" measurements. Organic carbon determinations could not be made on these residues, due to shipboard removal of carbonate, but they are adequate for organic petrography and represent an economic use of the sediment available. The samples range in age from Oligocene/Miocene at 511 meters to Hauterivian at 1736.5 meters. The majority of the samples represent Lower Cretaceous sediments.

\section{METHODS}

The methods used for organic petrography by these laboratories are described in our Leg $47 \mathrm{~A}$ report (Cornford et al., Volume 47, Part 2). During this study, the procedure was modified by addition of a hydrofluoric acid step $\left(50^{\circ} \mathrm{C}\right.$ for 20 hours) prior to density floatation. This resulted in higher and more representative yields of kerogen concentrate: it does not remove all silicates, but appears to loosen the bond between them and the kerogen particles.

\section{RESULTS}

The samples investigated are listed in Table 1, where age and depth $( \pm 0.5 \mathrm{~m})$ are given. The type of

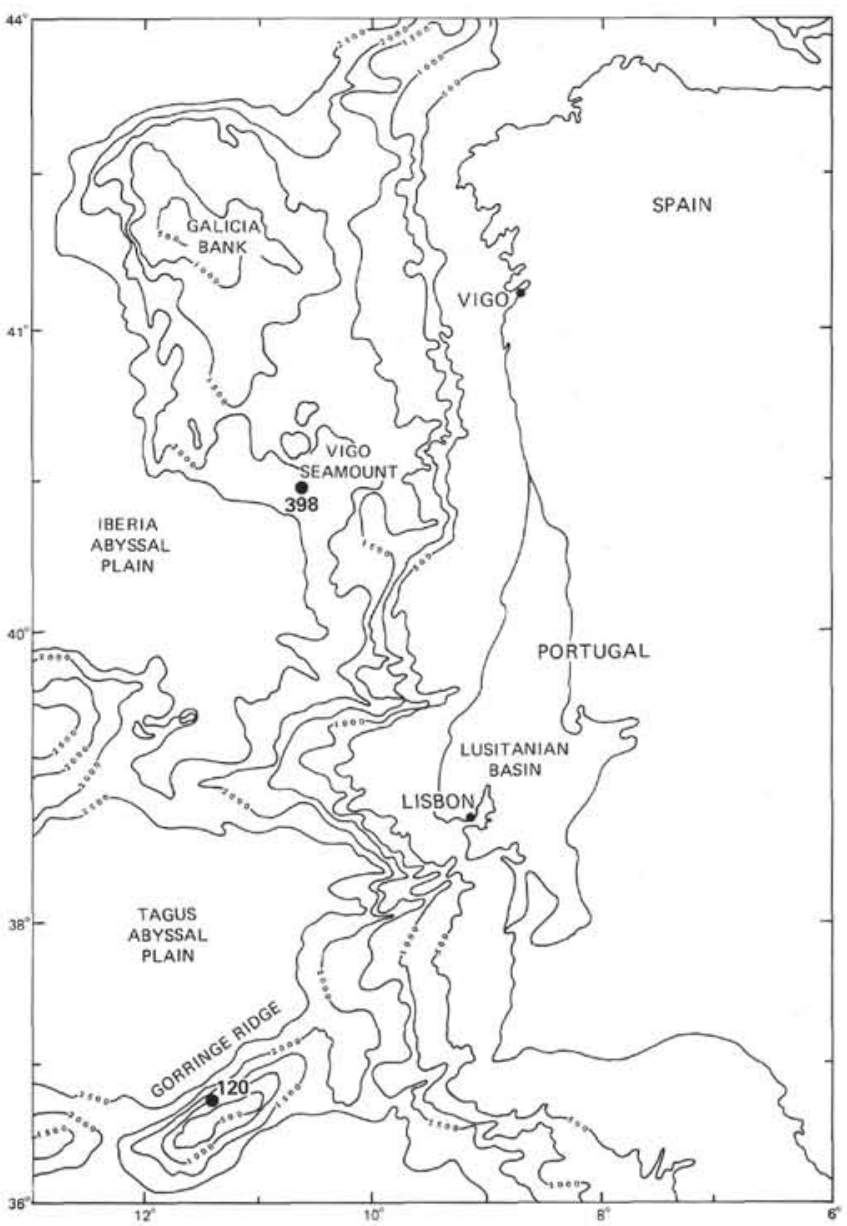

Figure 1. Location and bathymetry of DSDP Site 398.

particles present in each sample is also quantified and briefly described. Visual estimates of areal percentages are given, and gross composition has been checked in transmitted light using strewn slide preparations. In re- 


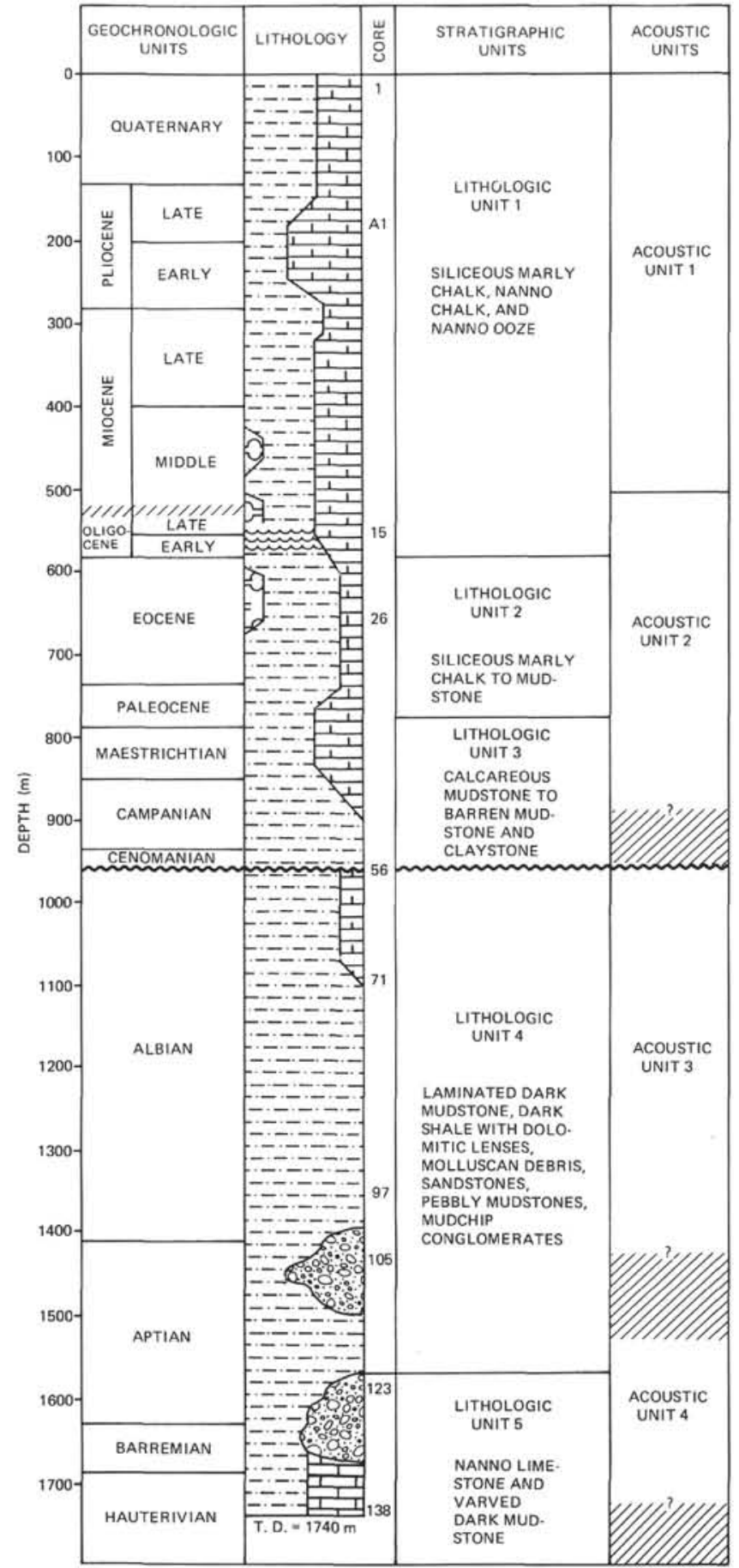

Figure 2. Stratigraphy and sedimentology of DSDP Site 398.

flected light, a distinction is made between typical rounded to subangular gray reflecting particles of huminite-vitrinite type, and angular high reflecting (i.e., greater than about 2\% R) inertinite particles (Stach et al., 1975). Bituminite, if non-fluorescent, is included in the vitrinite figure. The liptinites are identified by their fluorescence under ultraviolet excitation (Teichmüller and Wolf, 1977). Structured particles such as spores, pollen, resin bodies, or cuticle have a characteristic shape: the identification of nonstructured particles and amorphous material is problematic, but probably derives from algal or bacterial biomass.

With our present knowledge, the majority of liptinitic particles in these sediments are generally not identifiable with any certainty. In this report, the "remarks" column in Table 1 contains a description of the major liptinite component, whether amorphous or structured, while the fluorescence intensity is described by bright (generally yellow) or dull (generally orange). Fluorescent "bitumens" are counted in the liptinite percentage.

In the Lower Cretaceous samples, the liptinites are of two types; generally amorphous structureless bright yellow fluorescing particles, and structured dull orange to non-fluorescing spores, cuticle, and other unidentified particles.

Reflectance values (oil; $546 \mathrm{~nm}$ ) were measured on 200 random particles for each sample: the resulting reflectance histograms are shown in Figure 3 for samples from the Lower Cretaceous. The percentage of the total particles counted that fell above $0.55 \%$ R (i.e., the stippled areas in Figure 3 ) is plotted against depth and stratigraphy in Figure 4. Table 2 gives the mean reflectance, standard deviation, and the number of values measured for those samples in which typical first-cycle huminite-vitrinite particles were identified (see Cornford et al., Volume 47, Part 1).

\section{DISCUSSION}

Data in Table 1 show that the Lower Cretaceous section contains a predominance of organic particles such as vitrinite, inertinite, and sporinite, all originating from higher plants. This indicates a major terrestrial source.

The broad and multimodal reflectance histograms (Figure 3 ) demonstrate that much of the organic matter in all samples is redeposited (Hagemann, 1974). The presence of redeposited organic matter is confirmed by the anomalously low intensity and reddish fluorescence exhibited by some spores and other liptinite particles. The redeposited organic matter must have been eroded from organic-rich sediments or coals which had reached rank levels in the 0.8 to 1.4 per cent reflectance range and which were uplifted prior to the Early Cretaceous. For example, Sample 118-2, 85-87 cm at 1546.5 meters contains a major narrow peak below 0.6 per cent reflectance $\left(R_{\text {mean }} 0.28 \%\right.$ and a broader peak from 0.6 to about 1.5 per cent reflectance $\left(R_{\text {mean }}\right.$ $0.94 \%$ ), stippled in Figure 3. The first peak results mainly from Cretaceous organic matter; the second from rocks or coals eroded from the sediment source area for Site 398. This second peak thus indicates the rank of the sediment source supplying this Lower Cretaceous basin of the young North Atlantic. No multi-macerites (particles containing more than one maceral type) were seen. This may suggest derivation from an organic-rich shale rather than a coal.

From the reflectance values the presence of organicrich sediments or coals of a high volatile bituminous to medium volatile bituminous rank are indicated in the source region. Jurassic sediments are unlikely to have 
TABLE 1

Samples Studied From DSDP Site 398 and the Maceral Analyses of the Kerogen Concentrates

\begin{tabular}{|c|c|c|c|c|c|c|}
\hline \multirow{2}{*}{$\begin{array}{c}\text { Sample } \\
\text { (Interval in } \mathrm{cm} \text { ) }\end{array}$} & \multirow{2}{*}{$\begin{array}{l}\text { Depth } \\
\text { (m) }\end{array}$} & \multirow[b]{2}{*}{ Age } & \multirow[b]{2}{*}{ V $(\%)$} & \multicolumn{3}{|c|}{ Maceral Analysis $^{\mathrm{a}}$} \\
\hline & & & & I $(\%)$ & $\mathrm{L}(\%)$ & Comments \\
\hline $12-2,80-82$ & 511.0 & Oligocene/Miocene & 10 & 10 & 80 & $\begin{array}{l}\text { Amorph, dull } \\
\text { fluorescence }\end{array}$ \\
\hline $36-3,92-94$ & 750.0 & Paleocene & 80 & $<1$ & 20 & $\begin{array}{l}\text { Brown cells }(15 \mu \mathrm{m}) \\
\text { clumps non-fl. }\end{array}$ \\
\hline $48-3,55-57$ & 864.5 & Campanian & - & - & - & No sample recovered \\
\hline $62-1,35-40$ & 1003.0 & Albian & 45 & 15 & 40 & Lipt. mixed \\
\hline $65-2,58-60$ & 1033.0 & Albian & 90 & 5 & 5 & Redeposited vitrinites \\
\hline $77-2,50-52$ & 1166.0 & Albian & 80 & 15 & 5 & As above \\
\hline $99-2,64-65$ & 1365.5 & Albian & 75 & 5 & 20 & $\begin{array}{l}\text { Lipt. dull amorph. + } \\
\text { dull struct. }\end{array}$ \\
\hline $111-3,134-136$ & 1482.0 & Aptian & - & - & - & No sample recovered \\
\hline $113-2,85-87$ & 1499.0 & Aptain & 65 & 5 & 30 & As in section $99-2$ \\
\hline $118-2,85-87$ & 1546.5 & Aptian & 85 & $<1$ & 15 & $\begin{array}{l}\text { Lipt mostly bright } \\
\text { amorph. }\end{array}$ \\
\hline $119-5,14-24$ & 1559.0 & Aptian & 35 & 45 & 20 & $\begin{array}{l}\text { Lipt. mostly dull } \\
\text { struct. }\end{array}$ \\
\hline $120-3,114-116$ & 1567.0 & Aptian & 70 & 1 & 30 & As above \\
\hline $123-3,85-86$ & 1595.5 & Aptian & 60 & 1 & 40 & $\begin{array}{l}\text { Lipt. mainly bright } \\
\text { amorph. }\end{array}$ \\
\hline $124-4,30-33$ & 1606.0 & Aptian & 70 & 10 & 20 & As above \\
\hline $126-1,114-116$ & 1621.0 & Aptian & 40 & 40 & 20 & Lipt. bright amorph. \\
\hline $126-4,0-10$ & 1624.5 & Aptian & 45 & 15 & 40 & $\begin{array}{l}\text { Lipt. mostly dull } \\
\text { struct. }\end{array}$ \\
\hline $127-2,42-44$ & 1631.5 & Aprian & 60 & 30 & 10 & $\begin{array}{l}\text { Lipt. dull amorph.+ } \\
\text { struct. }\end{array}$ \\
\hline $128-3,65-66$ & 1642.5 & Barremian & 50 & 10 & 40 & $\begin{array}{l}\text { Lipt. mainly bright } \\
\text { amorph. }\end{array}$ \\
\hline $130-3,36-37$ & 1661.5 & Barremian & - & - & - & No sample recovered \\
\hline $132-3,90-91$ & 1681.0 & Barremian & 45 & 15 & 40 & Lipt. dull amorph. \\
\hline $134-1,77-78$ & 1697.0 & Hauterivian & 60 & 25 & 15 & As above \\
\hline $137-3,112-114$ & 1728.5 & Hauterivian & 50 & 40 & 10 & As avove \\
\hline $138-2,116-117$ & 1736.5 & Hauterivian & 50 & 25 & 25 & $\begin{array}{l}\text { Lipt. mainly dull } \\
\text { struct. }\end{array}$ \\
\hline
\end{tabular}

${ }^{\mathrm{a}}$ Dull, bright $=$ fluorescent intensity of liptinites; struct., amorph. $=$ structured or amorphous liptinite particles; $\mathrm{V}=$ humite-vitrinite, $\mathrm{I}=$ inertinite, $\mathrm{L}=$ Liptinites.

reached this rank; organic-rich sediments are not common in the Permo-Trias of Europe of eastern North America. Preserved carboniferous coal measures in this rank range occur both on the east and west sides of the (reconstructed) Galicia region of the early Atlantic. To the east were the carboniferous coal measures of the Sao Pedro da Cova and Asturias basins of Iberia, and to the west were the carboniferous bituminous and coking coal basins of Nova Scotia and Newfoundland (Matveev et al., 1972). Derivation from the north, from carboniferous coals on the continental shelf south and west of the British Isles, could also be possible. Evidence confirming these sources might be found in palynological studies.

On the basis of the redeposited organic matter, the section can be divided into two intervals. In the lowest (Interval I, Figure 4), represented by samples from 1736 to 1546 meters (Hauterivian-upper Aptian), first cycle organic matter (the reflectance peak in the 0.1 to $1.6 \% \mathrm{R}$ region) predominates (Figure 3 ). The upper interval (II), represented by samples from 1499 to 1003 meters (upper Aptian and Albian), contains a dominance of redeposited organic matter (Figure $3 a$ ). These intervals can be compared with the sedimentological units and stratigraphy in Figures 2 and 4, where it is seen that they correspond roughly to lithological Units 4 (Albian, Aptian) and 5 (Aptian, Barremian, and Hauterivian). This change in relative proportions, quantified in Figure 4, suggests that during the Hauterivian to early Aptian the organic input was derived from both Cretaceous land plants and rederived organic matter, while recycled material predominated by the late Aptian to Albian.

The primary vitrinite reflectance is not correctly represented by the lowest (unstippled) peak in the reflectograms of, for example, Samples 118-2, 85-87 cm; 


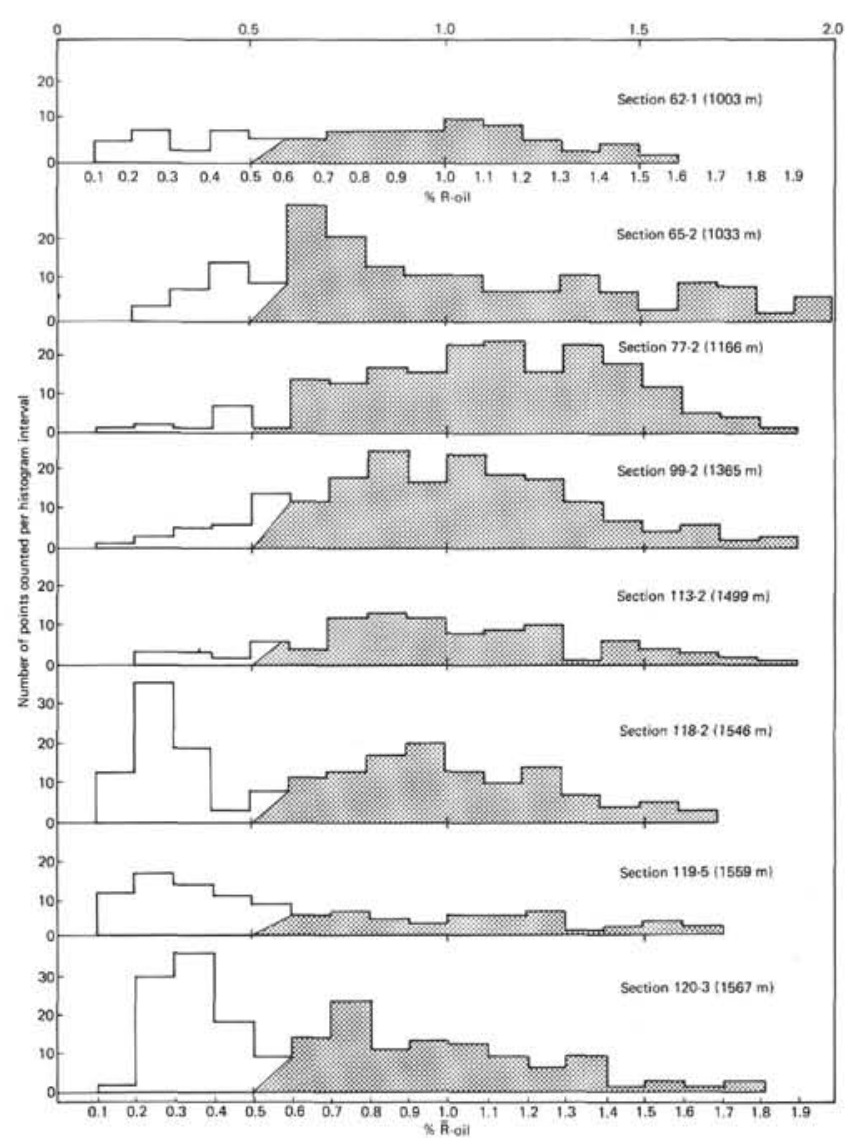

Figure 3a. Total reflectance histograms for organic particles from the Lower Cretaceous at DSDP Site 398, Albian and Aptian samples. (Stippled areas denote derived vitrinites.)

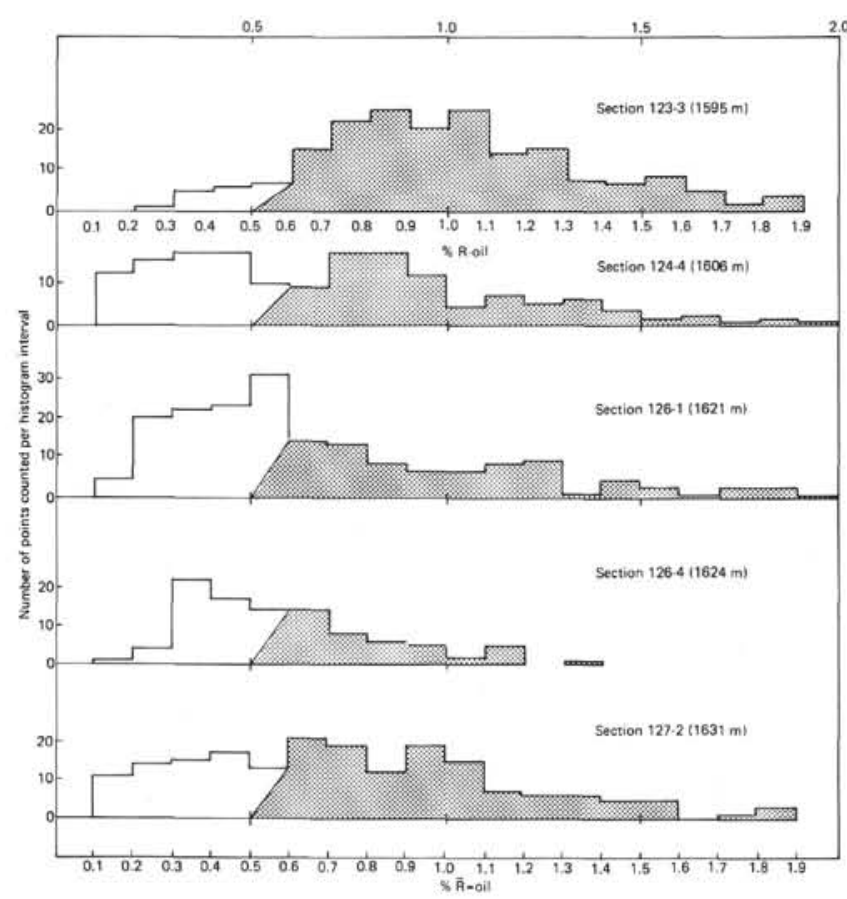

Figure $3 \mathrm{~b}$. Total reflectance histograms for organic particles from the Lower Cretaceous at DSDP Site 398, Aptian samples. (Stippled areas denote derived vitrinites.)

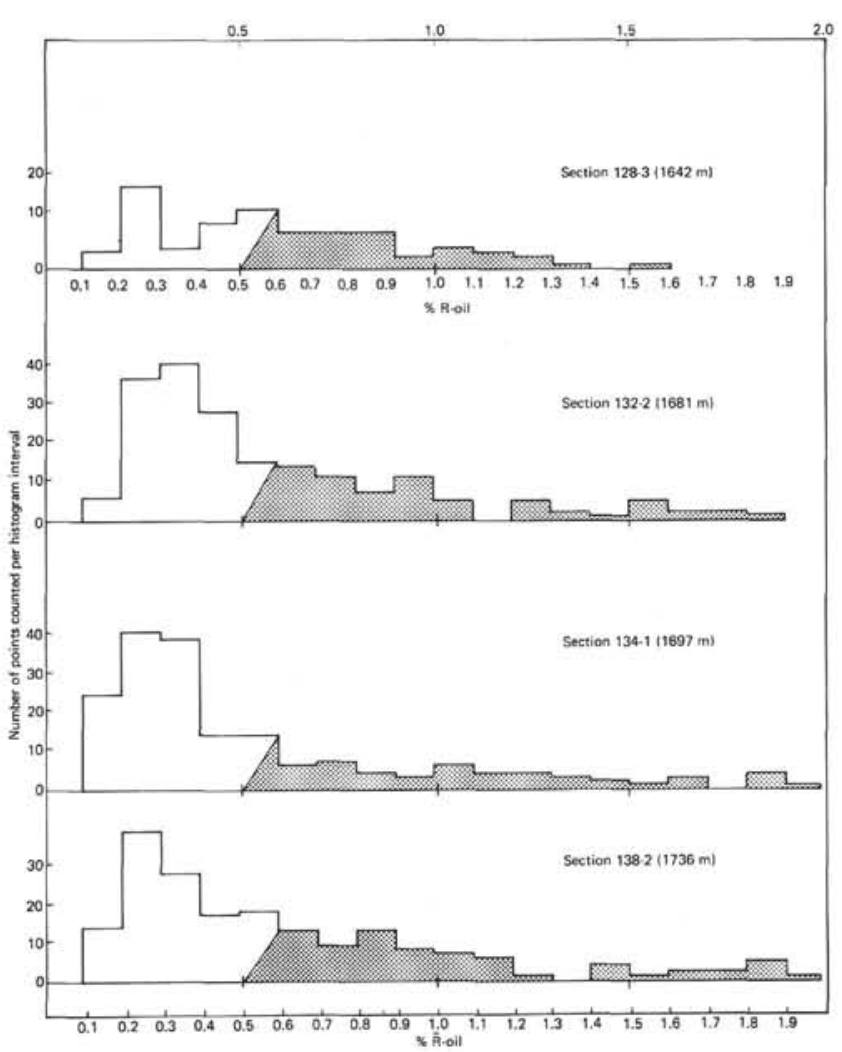

Figure 3c. Total reflectance histograms for organic particles from the Lower Cretaceous at DSDP Site 398, Barremian/Hauterivian samples. (Stippled areas denote derived vitrinites.)

120-3, 114-116 cm; and 138-2, 116-117 cm (Figure 3). In addition to first cycle vitrinite, these peaks also contain the liptinite (spores, cuticle) from the redeposited higher reflecting vitrinite populations, as well as particles that might be either humic matter or "bituminite." These latter particles appear in transmitted light preparations to be brown (at the edges), semi-translucent spheroids, about $20 \mu \mathrm{m} \pm 10$ in diameter. They are not soluble in "Canada balsam" mounting medium. In reflected light, they appear as circular low reflecting bodies, often showing splitting at the edges and fissuring. They exhibit very low intensity brown fluorescence and are not dissolved by epoxy resin. They form a distinct reflectance peak in the sample from Section 128-3 at 1642 meters (Figure 3c). Although no positive identification is possible, the lack of solubility in "Canada balsam" and the absence of marked fluorescence sug-

TABLE 2

Mean Reflectance Values, $(\% \overline{\mathrm{R}}-\mathrm{o})$ Standard Deviation, and Number of Particles Counted $(N)$ for First Cycle Vitrinite From the Lower Cretaceous, DSDP Site 398

\begin{tabular}{l|c|l|l|l|l|c}
\hline $\begin{array}{c}\text { Sample } \\
\text { (Interval in cm) }\end{array}$ & $\begin{array}{c}\text { Depth } \\
(\mathrm{m})\end{array}$ & \multicolumn{1}{|c|}{ Age } & $\% \overline{\mathrm{R}-\mathrm{o}}$ & Between & $N$ & Std. Dev. \\
\hline $124-4,30-35$ & 1606.0 & Aptian & 0.55 & $0.490-57$ & 10 & 0.02 \\
$126-1,114-116$ & 1621.0 & Aptian & 0.54 & $0.30-0.77$ & 25 & 0.14 \\
$126-4,0-10$ & 1624.5 & Aptian & 0.52 & $0.32-0.64$ & 38 & 0.09 \\
$127-2,42-44$ & 1631.5 & Aptian & 0.54 & $0.45-0.63$ & 14 & 0.06 \\
$128-3,65-66$ & 1642.5 & Barremian & 0.49 & $0.40-0.60$ & 27 & 0.05 \\
$132-3,90-91$ & 1681.0 & Barremian & 0.53 & $0.41-0.62$ & 13 & 0.07 \\
\hline
\end{tabular}




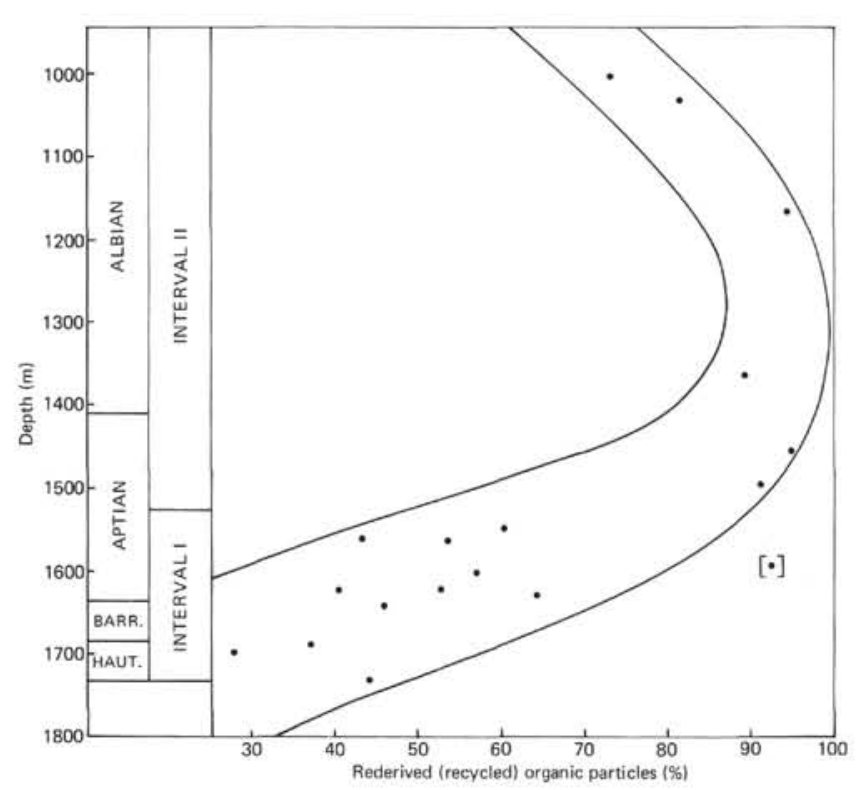

Figure 4. Percentage of redeposited organic matter as a function of depth, Lower Cretaceous DSDP Site 398. Horizontal axis represents per cent of particles with reflectance greater than 0.55 per cent taken from the stippled areas in Figures $3 a-c$.

gest they are not "bituminite." They may be a humic gel analogous to the gelinite in brown coals.

Typical, more angular, higher reflecting vitrinite, in some cases showing cellular outlines, generally exhibits a higher reflectance than the particles described above. Experience in these laboratories has shown that in such cases a more reliable reflectance trend is established by taking the mean of a few measurements made on wellpolished typical vitrinite. Data from such selected measurement are shown in Table 2 , and indicate mean vitrinite reflectance values of about 0.5 per cent at 1700 meters. No distinct trend with depth is observable.

This level of maturity $(0.5 \% \mathrm{R}$ at $1700 \mathrm{~m})$ suggests an average geothermal gradient $\left(0.5 \% \mathrm{R}=60^{\circ} \mathrm{C}\right.$; Demaison, 1975) of about $30^{\circ} \mathrm{C} / \mathrm{km}$. This does not agree well with the single shipboard measurement which extrapolates to give the low gradient of about $10^{\circ} \mathrm{C} / \mathrm{km}$ (Site Report, this volume). A value of 0.5 per cent reflectance was found at Site 397 to occur at a temperature of about $65^{\circ} \mathrm{C}$ (Cornford et al., Volume 47, Part 1). Here at Site 398 it occurs at about $20^{\circ} \mathrm{C}\left(3^{\circ} \mathrm{C}\right.$ at sea floor $+10^{\circ} \mathrm{C} / \mathrm{km}$ to $\left.1700 \mathrm{~m}\right)$. Either the shipboard measurement is not reliable, the low vitrinite itself was redeposited, or a higher geothermal gradient may have existed in the past. Higher geothermal gradients would be expected during the early stage of spreading. The bottom-hole sediments had been buried to nearly $1 \mathrm{~km}$ by the end of Cretaceous time.
An alternative possibility is that rapid sedimentation occurred during the $20 \mathrm{~m} . \mathrm{y}$. represented by the Cenomanian/Campanian unconformity at Core 56. If true, further burial of the sediments below Core 56 could have raised their reflectance level. Burial of at least 3 $\mathrm{km}$ would be necessary to reach the reflectance level found at the bottom of the hole, assuming the presentday measured gradient of $10^{\circ} \mathrm{C} / \mathrm{km}$. This would indicate an uncorrected sedimentation rate of $100 \mathrm{~m} / \mathrm{m} . \mathrm{y}$. for the entire 20 m.y. an extreme postulation.

The relatively low maturity of the Lower Cretaceous sediments, with vitrinite reflectance values reaching 0.5 per cent, indicates that they fall on the lower boundary for commercial hydrocarbon generation (Hood et al., 1975). The sediment section is therefore fairly safe as regards hazards resulting from the release of hydrocarbons.

The ability of the Lower Cretaceous sediments to produce significant hydrocarbons given sufficient burial might be reasonable, with many samples containing appreciable (20 to $40 \%$ ) liptinitic organic matter. But much of the lipinite is redeposited, showing anomalously low and orange-brown fluorescence. The generating potential of redeposited liptinites is unknown but is probably low. The Lower Cretaceous section can therefore only be rated as a fair potential hydrocarbon source rock.

\section{ACKNOWLEDGMENTS}

I would like to thank Mr. W. Benders and Ms. I. Jacobs for technical help with the microscopy, and Dr. H. W. Hageman (Technische Hochschule, Aachen) for reviewing the draft manuscript.

\section{REFERENCES}

Demaison, G. T., 1975. Relationship of coal rank to paleotemperatures in sedimentary rocks. Alpern, B. (Ed.), Paris, (C.N.R.S.), Colloque International, Pétrographie de la Matière Organique des Sédiments, Relations avec la $\mathrm{Pa}$ léotempérature et le Potentiel Pétrolier, p. 217.

Hagemann, H. W., 1974. Petrographische und palynologische Untersuchung der organischen Substanz (Kerogen) in den liassischen Sedimenten Luxemburgs. In Tissot, B. and Bienner, F. (Eds.), Advances in Organic geochemistry: Paris (Technip).

Hood, A., Gutjarh, C. C. M., and Heackock, R. L., 1975. Organic metamorphism and the generation of petroleum, American Assoc. Petroleum Geologists Bull., v. 59, p. 98.

Matveev, A. K., 1972. Map of the coal fields of the world; Moscow (Nedra), see: World Coal, September, 1976).

Stach, E., Mackowsky, M.-Th., Teichmüller, M., Taylor, G. H., Chandra, D., and Teichmüller, R., 1975. Stach's textbook of coal petrology: Berlin (Gebrüder-Bornträger).

Teichmüller, M. and Wolf, M., 1977. Application of fluorescence microscopy in coal petrology and oil exploration, Journal of Microscopy, v. 109, p. 49. 